\title{
Effect of PGF-2 $\alpha$ on serum progesterone levels in the swamp buffalo (Bubalus bubalis)
}

\author{
Maneewan Kamonpatana*, Annop Kunawongkrit $\dagger$, Prasit Bodhipaksha \\ and Yenchit Luvira $\S$
}

*Division of Biochemistry, Department of Physiology; Departments of $\dagger$ Animal Husbandry and $\ddagger$ Surgery and Obstetrics, Faculty of Veterinary Science; and §Department of Obstetrics and Gynaecology, Faculty of Medicine, Chulalongkorn University, Bangkok 5, Thailand

\begin{abstract}
Summary. Induction of some oestrous phenomena was achieved. Treatment with 25 mg PGF- $2 \alpha$ caused mucous discharge, within 48-72 $\mathrm{h}$ after injection, which lasted for 4-5 days. Rectal palpation indicated rapid regression of the $C L$, and in 9 treatments of 6 buffaloes serum progesterone levels declined from $1.76 \pm 0.01$ (s.d.) $\mathrm{ng} / \mathrm{ml}$ before treatment to $<0.25 \mathrm{ng} / \mathrm{ml}$ within $24 \mathrm{~h}$ after injection. Concentrations increased at about Day 11 and reached a peak of $1.78 \pm 0.62 \mathrm{ng} / \mathrm{ml}$ on Day 18.50 $\pm 2 \cdot 45$.
\end{abstract}

\section{Introduction}

The importance of the swamp buffalo (Bubalus bubalis) as a source of draught power and meat, particularly for the many small farmers in Asia, needs no emphasis, since $97 \%$ of the world's buffalo population are found in that continent. There is, however, an urgent need to increase productivity to meet the ever-increasing demand for both draught power and meat. Extensive and intensive study of the buffalo must be undertaken to achieve improved reproductive performance of these long-neglected domestic animals. One of the most effective ways of rapidly achieving genetic improvement in the buffalo would be by artificial insemination (A.I.). In contrast to cattle, A.I. has not been successfully practised with buffaloes.

The detection of oestrus in buffaloes under range conditions presents difficulties, and this is one of the major impediments to the widespread use of A.I. services. In cattle this problem can be overcome by the use of hormonal agents such as prostaglandins (PGs), which will not only induce oestrus but also bring about ovulation within about 4-5 days (Rowson, Tervit \& Brand, 1972; Lauderdale, 1972; Inskeep, 1973; Louis, Hafs \& Seguin, 1973; Roche, 1974). A regimen consisting of two injections of PGF-2 $\alpha$ 10-12 days apart synchronizes oestrus in animals at various stages of the cycle (Cooper, 1974; Hafs, Manns \& Drew, 1975) and fertility following insemination at the synchronized oestrus has been reported to be normal (Inskeep, 1973; Lauderdale et al., 1974; Roche, 1974; Cooper \& Jackson, 1975; Hafs et al., 1975; Edqvist, Settergren \& Astrom, 1975).

Oestrus and ovulation can be induced in the buffalo by treatment with a PGF-2 $\alpha$ analogue (Jainudeen, 1976a, b) and the successful application of such hormone treatments and A.I. in buffaloes (Kamonpatana, Luvira, Bodhipaksha \& Kunawongkrit, 1976; Kamonpatana, 1977) would be of immense value. The present experiments were primarily designed to determine the effect of parenteral administration of PGF-2 $\alpha$ on serum progesterone levels in the swamp buffalo. 


\section{Materials and Methods}

\section{Administration of PGF-2 $\alpha$ and blood sample collection}

The 6 buffaloes used were 3 to 7 years old and healthy. All the animals exhibited regular oestrous cycles $(22 \cdot 1 \pm 2.9$ days: Kamonpatana et al., 1976) and the normal development of follicles, ovaries and corpora lutea $(\mathrm{CL})$ was ascertained by daily rectal palpation. The animals were put out to pasture after 10:00 h each day but in the evenings they were housed and stall-fed with concentrates.

All 6 animals received a single intramuscular injection of $25 \mathrm{mg}$ PGF- $2 \alpha$ (tromethamine salt, Dinoprost: Upjohn Co.) on the 5th day of development of a CL. Three of the animals were given a similar dose of PGF-2 $\alpha$ in the next oestrous cycle. For 10 days after the PGF- $2 \alpha$ injection the condition of the ovary was assessed by rectal palpation every $12 \mathrm{~h}$ and the behaviour of the animals to each other was observed to detect oestrus.

For 10 days before and 30 days after administration of PGF-2 $\alpha$, blood samples for hormone analysis were collected from the jugular vein at 10:00 h every 2 days, and also once on the 1 st day, twice on the 2 nd day and 8 times on the 3rd day immediately after the injection. The blood was allowed to clot at $4^{\circ} \mathrm{C}$ for $4-6 \mathrm{~h}$ and the serum was separated, frozen and kept at $-20^{\circ} \mathrm{C}$ until assay.

\section{Progesterone assay}

Serum extraction. A volume of $1 \mathrm{ml}$ serum was mixed with $0.1 \mathrm{ml}$ of assay buffer containing 2000 d.p.m. (1000 c.p.m.) of $\left[{ }^{3} \mathrm{H}\right.$ ]progesterone (sp. act. $85 \mathrm{Ci} / \mathrm{mmol}$ : Radiochemical Centre, Amersham, U.K.). This tracer was used as an internal standard for recovery estimations. The mixture was equilibrated at room temperature for $30 \mathrm{~min}$. The extraction was carried out with petroleum ether (b.p. $40-60^{\circ} \mathrm{C}$ ) at 10 times the volume of serum for $1 \mathrm{~min}$. The lower phase was then quickly frozen by immersion in $95 \%$ ethanol containing chips of solid $\mathrm{CO}_{2}$, and the supernate was decanted, washed with $1 \mathrm{ml}$ distilled water and dried under filtered air.

Radioimmunoassay. The dry residue was dissolved at room temperature in $1.7 \mathrm{ml}$ phosphate buffer, $\mathrm{pH} 7 \cdot 0$, and left at room temperature for 1-2 h. An aliquot of $0.5 \mathrm{ml}$ was used for recovery estimation, and duplicate aliquots of $0.5 \mathrm{ml}$ were each mixed with $0.1 \mathrm{ml}$ diluted antiserum to progesterone (1:1500 dilution of the FO 22/5 antiserum given by Professor Edqvist, Department of Clinical Chemistry, Royal Veterinary College, Uppsala, Sweden) and incubated at room temperature for $1 \mathrm{~h}$. After addition of $0.1 \mathrm{ml}$ buffer containing 20000 d.p.m. (10 000 c.p.m.) of $\left[{ }^{3} \mathrm{H}\right]$ progesterone the reactant mixture was incubated at $4{ }^{\circ} \mathrm{C}$ overnight. In each set of assays, a quadruplicate set of three pools of serum containing $100-2500 \mathrm{pg}$ unlabelled progesterone in $1 \mathrm{ml}$ hormone-free serum was used as control. The standard curve was based on a set of standard progesterone solutions $(2 \cdot 5-1000 \mathrm{pg})$ in triplicate, run at the same time as the unknown samples.

After incubation at $4^{\circ} \mathrm{C}$ overnight, $0.2 \mathrm{ml}$ of a suspension containing $0.625 \%$ Norit $\mathrm{A}$ and $0.0625 \%$ dextran in assay buffer was added to the incubation media, mixed and incubated for 20 min in an ice bath at $4^{\circ} \mathrm{C}$. The samples were centrifuged for $20 \mathrm{~min}$ at $4^{\circ} \mathrm{C}$ at $2500 \mathrm{~g}$ and the supernatant was decanted into counting vials. After addition of $10 \mathrm{ml}$ counting solution the vials were placed in a liquid-scintillation spectrometer (Packard 3390) for counting.

Calculations. The amounts of progesterone in the buffalo serum samples were calculated by interpolation from the standard curve by the method explained to us by G. E. Abraham (personal communication).

Validation. The specificity of antiserum FO $22 / 5$ for buffalo serum was tested by cross-reaction (progesterone $100 \%$ ) studies with various steroids. Only 5 $\alpha$-pregnan-3,20-dione showed a cross-reaction $(67.8 \%)$; $17 \alpha$-hydroxyprogesterone, cortisone, corticosterone, cortisol, androstenedione, testosterone, oestrone, oestradiol $-17 \beta$ and oestriol showed no cross-reaction. The 
accuracy was tested by measuring known amounts of progesterone in $1 \mathrm{ml}$ progesterone-free serum from a male buffalo: the recoveries for 250,500 and $2500 \mathrm{pg}$ progesterone were 94.96 , 97.58 and $102.51 \%$ respectively. The within-assay variance was evaluated by 5 duplicate determinations of each of 3 pools in the same assay and, when expressed as a coefficient of variation (C.V.) for values ranging from 250 to $2500 \mathrm{pg} / \mathrm{ml}$, was $2.68 \%$. The between-assay C.V. was calculated from the results obtained from 5 duplicate determinations in 5 different assays and was $10.12 \%$. The sensitivity of the method, twice the s.d. of the blank, was $3.0-20.0 \mathrm{pg}$ progesterone.

\section{Results}

\section{Clinical observations}

The 6 selected buffalo cows were all at normal dioestrus at the time of PGF-2 $\alpha$ injection and their $\mathrm{CL}$ were about $6-9 \mathrm{~mm}$ in diameter.

The injection of PGF-2 $\alpha$ resulted in a progressive reduction in diameter of the CL from 6 to $3 \mathrm{~mm}$ or less. The animals usually showed signs of contraction of the uterus on the day following the injection. They often had a slight mucous discharge $48-72 \mathrm{~h}$ after the injection and for the next 4-5 days. A Graafian follicle was always palpable by $24-72 \mathrm{~h}$ after treatment and slight symptoms of oestrus at 2-4 days were recognized by the mounting behaviour of the females to each other. Such oestrous behaviour was more pronounced at the oestrus after the induced oestrus. The length of the oestrous cycle after PGF-2 $\alpha$ treatment did not differ significantly from that of control cycles in the same animals.

\section{Serum progesterone levels}

The levels of progesterone were measured during 9 oestrous cycles of the 6 treated buffaloes. After treatment, progesterone levels decreased sharply (Text-fig. 1) and remained low until about Day 11, when they began to increase to maximum values at Day 18-19 (Table 1). The changes in progesterone concentrations in the cycle after PGF-2 $\alpha$ treatment resembled those in untreated buffalo cows (Text-fig. 1).

More frequent sampling in the 3 days immediately after treatment showed a continuing low level of $0.21-0.81 \mathrm{ng}$ progesterone $/ \mathrm{ml}$.

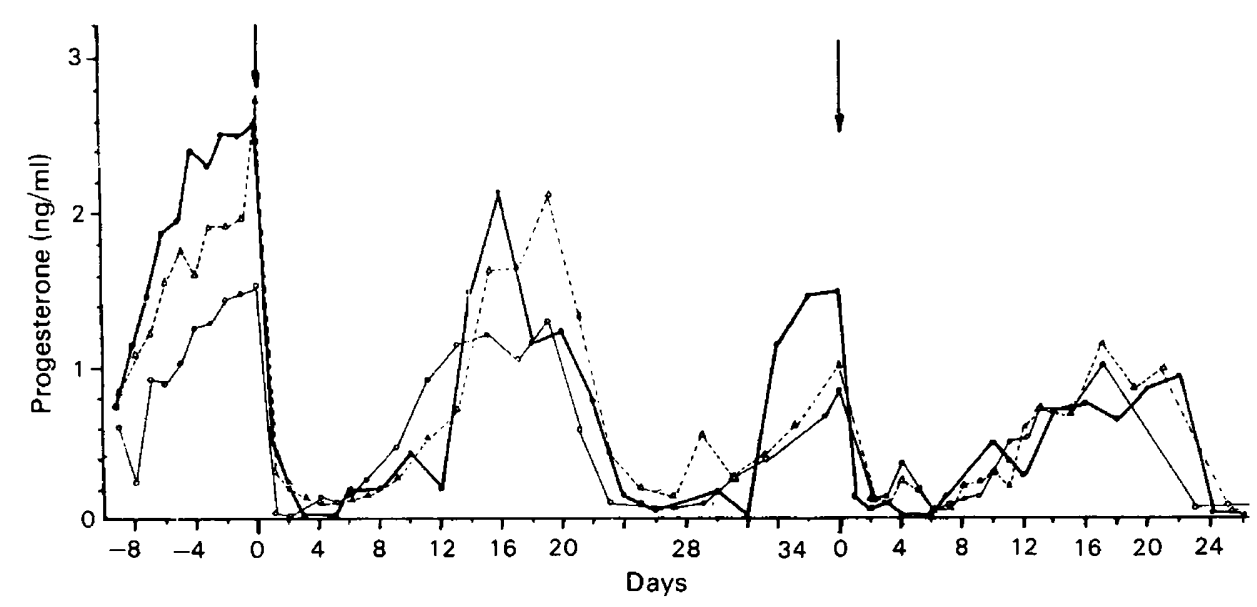

Text-fig. 1. Serum concentrations of progesterone in Buffaloes $4(--0), 7(0-0)$ and 8 $(\triangle-\longrightarrow \triangle)$ before and after intramuscular injections (arrows) of $25 \mathrm{mg}$ PGF- $2 \alpha$. 
Table 1. Serum progesterone concentrations $(\mathrm{ng} / \mathrm{ml}$ ) in buffaloes before (Day 0$)$ and after treatment with $25 \mathrm{mg}$ PGF- $2 \alpha$

\begin{tabular}{|c|c|c|c|c|c|c|c|c|c|c|c|c|}
\hline \multirow[b]{2}{*}{ Buffalo } & \multicolumn{10}{|c|}{ Days after treatment } & \multicolumn{2}{|c|}{ Peak values } \\
\hline & 0 & 1 & 2 & 3 & 4 & 5 & 6 & 7 & 9 & 11 & Day & Conc. \\
\hline 2 & 1.60 & $0 \cdot 10$ & 0.01 & 0.11 & 0.01 & 0.01 & 0.01 & 0.02 & 0.20 & 0.21 & 15 & 1.99 \\
\hline $4(1)$ & 2.58 & 0.55 & 0.55 & 0.25 & 0.10 & 0.19 & 0.18 & 0.19 & 0.18 & 0.20 & 17 & 0.90 \\
\hline (2) & 1.47 & 0.13 & 0.06 & 0.08 & 0.04 & 0.03 & 0.01 & 0.12 & 0.04 & 0.37 & 22 & 0.90 \\
\hline 5 & 1.63 & 0.39 & 0.32 & 0.41 & 0.39 & 0.03 & 0.07 & 0.01 & 0.05 & 0.21 & 22 & $2 \cdot 37$ \\
\hline 6 & 1.98 & 0.21 & 0.18 & 0.26 & 0.22 & 0.34 & 0.79 & 0.78 & 1.76 & $2 \cdot 21$ & 17 & 2.92 \\
\hline $7(1)$ & 1.89 & 0.02 & 0.01 & 0.19 & 0.14 & $0 \cdot 10$ & 0.16 & 0.27 & 0.57 & $1 \cdot 10$ & 19 & 1.57 \\
\hline (2) & 1.00 & 0.13 & 0.13 & 0.43 & 0.20 & 0.03 & 0.09 & 0.12 & 0.36 & 0.68 & 16 & $1 \cdot 20$ \\
\hline $8(1)$ & 2.74 & 0.29 & 0.18 & 0.11 & $0 \cdot 10$ & 0.09 & 0.11 & 0.12 & 0.23 & 0.52 & 19 & $2 \cdot 11$ \\
\hline (2) & 0.99 & $0 \cdot 10$ & 0.09 & 0.22 & $0 \cdot 18$ & 0.06 & 0.01 & 0.06 & 0.31 & 0.57 & 16 & $1 \cdot 32$ \\
\hline $\begin{array}{l}\text { Mean } \\
\pm \text { s.d. }\end{array}$ & $\begin{array}{r}1.76 \\
\pm 0.01\end{array}$ & $\begin{array}{r}0.21 \\
+0.17\end{array}$ & $\begin{array}{r}0.14 \\
\pm 0.11\end{array}$ & $\begin{array}{r}0.22 \\
\pm 0.13\end{array}$ & $\begin{array}{r}0.16 \\
\pm 0.11\end{array}$ & $\begin{array}{r}0.13 \\
\pm 0.12\end{array}$ & $\begin{array}{r}0.15 \\
\pm 0.23\end{array}$ & $\begin{array}{r}0.19 \\
\pm 0.24\end{array}$ & $\begin{array}{r}0.41 \\
\pm 0.53\end{array}$ & $\begin{array}{r}0.70 \\
\pm 0.63\end{array}$ & $\begin{array}{l}18.5 \\
\pm 2.45\end{array}$ & $\begin{array}{r}1.78 \\
\pm 0.62\end{array}$ \\
\hline
\end{tabular}

\section{Discussion}

The reliability of a radioimmunoassay for steroids depends on the degree of purification of the biological material before assay, the specificity of the antiserum used, the relative concentrations of the cross-reacting steroids in the fluid being assayed and the nonspecific interference by serum lipids and proteins. The present study reports a radioimmunoassay for serum progesterone requiring only solvent extraction without chromatography because of the highly specific antiserum to progesterone which was used. Although the progesterone concentrations measured in this study were 2-3 times higher than those obtained by radioimmunoassay with chromatography (Kamonpatana, 1977), probably because of the highly specific antiserum used, they were still extremely low, as previously found by Kamonpatana et al. (1976).

Injections of PMSG or stilboestrol, or administration of melengestrol acetate in the food, have been used to induce oestrus in buffaloes (Bhattacharya, 1974; Shukla, Mithuji \& Buch, 1972), but none of these techniques gave consistent results in terms of oestrus, ovulation and fertility. Administration of a PGF-2 $\alpha$ analogue (ICI 80,996) as two intramuscular injections did give effective induction of oestrus in buffaloes (Jainudeen, 1976b).

In general the pattern of the progesterone changes in buffaloes was similar to that reported for cows (Lauderdale, Chenault, Seguin \& Thatcher, 1973; Louis et al., 1973; Edqvist et al., 1975; Hoffman, Schams \& Karg, 1976) but the concentrations of progesterone before and after treatment were 2-6 times lower than those in cows and there was no pronounced preovulatory peak.

We conclude that PGF-2 $\alpha$ caused rapid regression of the CL and hence reduction of serum progesterone to basal values within $24 \mathrm{~h}$ after injection. Oestrus was apparently induced within 48-72 $\mathrm{h}$ after injection and up to 4-5 days afterwards, according to the discharge of mucus observed. This rather long period of mucous discharge would make the timing of successful insemination difficult, but measurements of LH concentrations could help to indicate the optimum time of insemination.

We thank Professor L. E. Edqvist for progesterone antiserum, Dr Prasit Thammasaeng for PGF-2 $\alpha$ from the Upjohn Company Limited, Mr Chokchai Bulakul for the experimental buffaloes, and Professor C. R. Austin for help with the MS. This study was supported by the International Atomic Energy Agency (IAEA), Research contract No. 1858/RB, and Rachadapiseksompot Research Fund, Chulalongkorn University, Thailand. 


\section{References}

Battcharya, P. (1974) Reproduction. In The Husbandry and Health of the Domestic Buffalo. Ed. W. Ross Cockrill. FAO, Rome.

Cooper, M.J. (1974) Control of the bovine oestrous cycle with synthetic prostaglandin analogue. Vet. Rec. 95, 200-203.

Cooper, M.J. \& Jackson, P. (1975) Control of the bovine oestrous cycle with a synthetic prostaglandin analogue ICI-80996; preliminary field experiences in lactating beef cattle. Proc. Br. Soc. Anim. Prod. 4, $115-116$.

Edqvist, L-E., Settergren, I. \& Astrom, G. (1975) Peripheral plasma levels of progesterone and fertility after prostaglandin $F_{2 a}$ induced estrus in heifers. Cornell Vet. 65, 120-131.

Hafs, H.D., Manns, J.G. \& Drew, B. (1975) Onset of oestrus after prostaglandin $\mathrm{F}_{2 \alpha}$ in cattle. Vet. Rec. 96 , 134-135.

Hoffimann, B., Schams, D. \& Karg, H. (1976) Cycle synchronisation under hormonal control. In Egg Transfer in Cattle. Ed. L.E.A. Rowson. E.E.C. Seminar, Cambridge.

Inskeep, E.K. 1973) Potential uses of prostaglandins in control of reproductive cycles in domestic animals. $J$. Anim. Sci. 36, 1149-1157.

Jainudeen, M.R. (1976a) Induction of oestrus and ovulation in buffalo (Bubalus bubalis) using cloprostenol, a synthetic analogue of prostaglandin $\mathbf{F}_{2 \alpha}$. Kajian Vet. 8, 40-42.

Jainudeen, M.R. (1976b) Induction of oestrus and ovulation in buffalo (Bubalus bubalis) using a prostaglandin $F_{2 \alpha}$ analogue (I.C.I. 80996). Proc. 8th Int. Congr. Anim. Reprod. \& A.I., Krakow, 3, $470-472$.
Kamonpatana, M. (1977) Some aspects of steroids radioimmunoassay (RIA) involved in the study of weak oestrous phenomenon of swamp buffalo. Thai J. vet. Med. 7, 46 .

Kamonpatana, M., Luvira, Y., Bodhipaksha, P. \& Kunawongkrit, A. (1976) Serum progesterone, 17hydroxyprogesterone and 17 $\beta$-oestradiol during oestrous cycle in the swamp buffalo in Thailand. In Nuclear Techniques in Animal Production and Health pp. 569-578. IAEA, Vienna.

Lauderdale, J.W. (1972) Effects of PGF ${ }_{2 \alpha}$ on pregnancy and estrous cycle of cattle. J. A nim. Sci. 35, 246.

Lauderdale, J.W., Chenault, J.R. Seguin, B.E. \& Thatcher, W.W. (1973) Fertility of cattle after PGF treatment. J. Anim. Sci. 37, 319.

Lauderdale, J.W., Seguin, B.E., Stellfiug, J.N., Chenault, J.R., Thatcher, W.W., Vincent, C.K. \& Loyancano, A.F. (1974) Fertility of cattle following $\mathrm{PGF}_{2 \alpha}$ injection. J. Anim. Sci. 38, 964-967.

Louis, T.M., Hafs, H.D. \& Seguin, B.E. (1973) Progesterone, LH, estrus and ovulation after prostaglandin $\mathrm{F}_{2 \alpha}$ in heifers. Proc. Soc. exp. Biol. Med. 143, 152-155.

Roche, J.F. (1974) Synchronization of oestrus and fertility following artificial insemination in heifers given prostaglandin $\mathrm{F}_{2 \alpha^{*}} . J$. Reprod. Fert. 37, 135-138.

Rowson, L.E.A., Tervit, H.R. \& Brand, A. (1972) The use of prostaglandins for synchronization of oestrus in cattle. J. Reprod. Fert. 29, 145-148.

Shukla, K.P., Mithuji, G.F. \& Buch, N.C. (1972) Induction of postpartum oestrus in Surti buffaloes treated with melengestrol acetate. Ind. J. Anim. Sci. 42, 993-995.

Received 10 August 1978 